\title{
Methanol as antifreeze agent for cold start of automotive polymer electrolyte membrane fuel cells
}

which has been published in final form in APPLIED ENERGY [https://doi.org/10.1016/j.apenergy.2019.01.036].

Florian Knorr ${ }^{1}$, Daniel Garcia Sanchez ${ }^{1}$, Johannes Schirmer ${ }^{1}$, Pawel Gazdzicki ${ }^{1 *}$, K. A. Friedrich ${ }^{1,2}$

${ }^{1}$ German Aerospace Center (DLR), Institute of Engineering Thermodynamics, Pfaffenwaldring 38-40, 70569 Stuttgart, Germany

${ }^{2}$ University of Stuttgart, Institute of Building Energetics, Thermal Engineering and Energy Storage (IGTE), Pfaffenwaldring 31, 70569 Stuttgart, Germany

*Corresponding author:

email address: pawel.gazdzicki@dlr.de (P. Gazdzicki)

phone: $\quad+49(0) 71168628094$

fax: $\quad+49(0) 7116862747$

Highlights:

- Methanol solution is suitable as antifreeze for freeze-thaw cycling of PEMFC MEAs

- Antifreeze eliminates performance losses due to freezing for $\mathrm{j}<1.6 \mathrm{Acm}^{-2}$

- Antifreeze allows PEMFC operation at sub-zero temperatures during cold-start 


\section{ABSTRACT}

One challenge for polymer electrolyte membrane fuel cells (PEMFCs) for electric vehicles is to ensure cold start capability and longevity under freeze-thaw $(F / T)$ cycling. Today, PEMFCs undergo dry gas purging to remove residual water before a cold shut-down to avoid degradation due to icing. This study investigates an alternative procedure with alcohol-water solution as antifreeze. In order to demonstrate the suitability of methanol as antifreeze, $F / T$ cycling tests using methanol have been compared with conventional dry gas purging of the cell before $F / T$ cycling. The results show that performance degradation upon $\mathrm{F} / \mathrm{T}$ cycling is mitigated when flooding the cell with the antifreeze prior to F/T cycling. Specifically, performance losses are observed at high current densities only and the peak performance of the cell does not decrease. Moreover, cold start procedures are examined to allow a start-up of the cell after being soaked with the antifreeze. In this context it is found that PEMFC operation is possible at sub-zero temperature if residual methanol is in the cell. However, residual methanol decreases power density during cold start. Hence, methanol needs to be removed from the cell by reaction or by prolonged water purging to reach nominal power.

Keywords: Polymer electrolyte membrane fuel cell, automotive, cold start, freeze-thaw cycling, antifreeze

\section{INTRODUCTION}

One of the most serious issues of the modern society is the increasing world energy demand which is mainly based on depletable fossil fuels such as oil, coal and gas. Burning of these fossil fuels leads to global warming and pollution caused greenhouse gas (GHG) emissions. Therefore, solutions to reduce GHG emissions are urgently needed. An obvious approach is using renewable energies such as wind or solar. These renewables, however, are intermittent and therefore require a storage concept. A promising solution is the coupling of electricity produced using renewable energy to a 
water electrolyzer which converts the electrical energy into chemically stored energy in form of hydrogen. The stored hydrogen can be used as fuel for fuel cells that convert hydrogen and oxygen (from ambient air) to electricity with water being the only exhaust product. In this context fuel cells are considered as a promising solution to replace internal combustions engines in vehicles in near future and contribute to reduction of GHG emissions. However, polymer electrolyte membrane fuel cells (PEMFCs) for automotive applications have to meet challenging cost, performance, and durability targets to be competitive.

One of the key requirements for fuel cell electric vehicles (FCEVs) is longevity with a targeted lifetime of the fuel cell of 5000 - $6000 \mathrm{~h}$. This lifetime needs to be assured considering not only PEMFC operation, but also various critical events such as start-stop [1] and freeze-thaw (F/T) cycling that regularly occur during a life of a FCEV. Specifically, a cold start capability at $-30^{\circ} \mathrm{C}$ is required [2].

Although PEMFCs seem to be one of the most promising alternatives to internal combustion engines for transportation purpose, there are still challenges that should be solved. One of them is the proper control of the water management assuring the minimum amount of water that is needed to maintain proton conductivity of the ionomer and membrane [3] and, in parallel, removing excess water from the porous media to avoid gas starvation by flooding $[4,5]$. When exposing the cell to temperatures < $0^{\circ} \mathrm{C}$, the water in the cell will freeze leading to ice formation in the membrane electrode assembly (MEA) components inducing premature degradation of the cell components. The degradation of the gas diffusion layer (GDL) structure upon freezing was studied in the works by Lee et al. [6] and Table et al. [7] and considered in the review article by Park et al. [8]. Regarding operation strategy, cold start can be realized by maximizing heat dissipation to minimize operation time at sub-zero temperatures [9]. In parallel, solutions on the material level are proposed, e.g. in order to improve the cold start capability some authors developed modifications in the MPL as proposed by Ko et al. [10] showing that additional pore volume for ice storage and using ionomer as MPL binder instead of PTFE are beneficial for a successful cold start. Some works [11] explore the cathode CL parameters such as the ionomer fraction and weight ratio of Pt to carbon support, and found that larger ionomer 
fraction and lower weight ratio of Pt to carbon support were beneficial for improving cold start capability. The majority of works $[13,14]$ have shown that the mainstream of the residual water was located in the GDL and gas channel, not on the $\mathrm{CL}$. According to simulations on water freezing during cold start published by Huo et al. [15] water preferably freezes at the interface between the catalyst layer and the micro porous layer. Moreover, not only MEA materials affect cold start capability of the PEMFC, but also the used flow field design (e.g. channel flow field versus porous mesh) [16].

Since freezing water in the cell cause damage to the MEA components, it is clear that minimizing the amount of liquid water before bringing the cell to $\mathrm{T}<0^{\circ} \mathrm{C}$ is a key requirement to a successful cold start $[17,18]$. Hence, cold start behavior of PEMFC is investigated by modelling as well as by experiments [19]. Numerous groups, such as Lee et al. [20], Tajiri et al. [21], Sinha et al. [22] or Kim et al. [23] investigated gas purge drying approaches to get rid of residual water from the cell. For instance, to improve the dry gas method Kim et al. [23] supplied small amount of hydrogen directly to the cathode. The so produced heat allowed greatly increasing the amount of residual water evaporation in the $\mathrm{CL}$ and GDL. Other alternatives to dry gas purging are drying by pressure reduction (or vacuum assisted drying) $[24,25]$ or using antifreeze which prevents freezing of water inside the cell $[26,27]$. Potential antifreezes are alcohol water-solutions such as investigated by Cho et al. [27] or Corti et al. [28]. According to Cho et al. [27] methanol and ethylene glycol are promising due to minimum swelling of the perfluorosulfonic acid (PFSA) membrane which reduces mechanical stress. Using the antifreezes no performance degradation was detected after $15 \mathrm{~F} / \mathrm{T}$ cycles, while $2.8 \%$ voltage loss/cycle was measured without the antifreeze; however, these results evaluate cell behavior at OCV and $600 \mathrm{mV}$ only.

As turned out in this study, icing inside the cell repeatedly occurring upon F/T cycling has strongest impact on the mass transport region of the performance curve; i.e. investigations in high current density range are of particular interest. A major point that needs still to be clarified is the cold start capability of the cell by using the antifreeze, which could not be solved yet and which is of great relevance for application in FCEVs. 
Once the antifreeze concept can be established it would provide several advantages over conventional pre-conditioning of the cell (purging with dry gases) before storage of the PEMFC at sub-zero temperature. In case of dry gas purging the purge time can take several minutes while filling of the cell with the antifreeze takes only seconds. Additionally, the power demand of balance of plant will also be unchanged compared to conventional systems, as no additional heater components are needed. Moreover, degradation of the MEA upon freeze-thaw is mitigated by the antifreeze which has a positive effect on the durability (and consequently cost) of the entire PEMFC stack.

\section{EXPERIMENTAL}

\subsection{Test stand and equipment}

The single cell test stand used in this study was developed in-house at the department of Electrochemical Energy Technology at the German Aerospace Center (DLR). The test bench was equipped with programmable logic controllers and commercial electronic loads. The gas mass flow rates were regulated at the cell inlets whereas the pressure was controlled at the cell outlets. For the humidification of the gases water evaporators from Bronkhorst High-Tech B.V. were used. The feed lines of the gases were kept at temperatures $5 \mathrm{~K}$ above cell temperature in order to avoid water condensation. Freeze-thaw cycling experiments were performed using a programmable Huber cooling circulator Ministat 230 which uses a silicon oil as coolant and was connected by thermally insulated tubing with the test cell.

The test stand was extended by a dedicated antifreeze filling system. The antifreeze (methanol-water solution with 40 vol\% methanol content) was filled into the cell and removed from the cell by purging with dry $\mathrm{N}_{2}$. Optionally, the cell can be flushed with DI-water to remove residual methanol solution.

The test cell was a qCF Liquid Cooling from Baltic FuelCells with graphitic plates with a 5-channel serpentine flow field. The electrochemical impedance spectroscopy (EIS) and cyclic voltammetry (CV) 
was conducted using a PP241 potentiostat of a ZAHNER ZENNIUM electrochemical workstation with THALES software.

\subsection{Tested MEAs}

Test object were commercial 7-layer MEAs with $5 \times 5 \mathrm{~cm}^{2}$ active area from EWII Fuel Cells $A / S$ (purchase date: September 2017). The MEAs are composed of a PFSA membranes and Pt/C catalyst at anode and cathode. Additionally, identical MEAs, but with a PtRu/C anode were made by EWII Fuel Cells $A / S$ following DLR's design suggestion for specific tests. If not indicated explicitly, then the Pt/Pt (anode/cathode) MEAs are used as standard test objects in this paper. The anode and cathode Pt loading was estimated from CV measurements to be 0.1 and $0.25 \mathrm{mg}_{\mathrm{Pt}} \mathrm{cm}^{-2}$, respectively.

\subsection{Nominal cell operation conditions}

The cells were operated using $\mathrm{H}_{2}$ (5.0 purity) and air (filtered and pressurized ambient air) with stoichiometries of 1.3 and 1.5 (minimum gas flows corresponding to a current density of $0.2 \mathrm{Acm}^{-2}$ ). Cell temperature was kept at $80^{\circ} \mathrm{C}$ and the relative humidities of $\mathrm{H}_{2}$ and air were set to $100 \%$. The respective anode and cathode absolute gas pressure was 2500 and 2300 mbar.

The breaking-in of the MEA consisted of $1.5 \mathrm{~h}$ operation at nominal conditions at $1 \mathrm{Acm}^{-2}$, followed by a shut-down (stop operation, cool down to ambient temperature for $1 \mathrm{~h}$, see [29]) and subsequent operation at nominal conditions at $1 \mathrm{Acm}^{-2}$ for $2 \mathrm{~h}$. After this procedure the change of cell voltage at $1 \mathrm{Acm}^{-2}$ was estimated to be below $5 \mathrm{mV} / \mathrm{h}$.

\subsection{Electrochemical characterization}

In the frame of electrochemical characterization as a first step a performance curve was recorded, followed by EIS measurements and eventually followed by CV of the anode and cathode:

- The performance curves were measured starting at $0 \mathrm{Acm}^{-2}$ and increasing the current stepwise up to $1.8 \mathrm{Acm}^{-2}$ according to Ref. [30]. 
- The impedance spectra were measured in the frequency range $100 \mathrm{mHz}$ to $10 \mathrm{kHz}$ directly after acquiring the performance characteristics. The load was set to $1 \mathrm{~A} \mathrm{~cm}^{-2}$ and the perturbation amplitude was $0.02 \mathrm{Acm}^{-2}$.

- Cyclic voltammetry (CV) measurements were performed in the range 0.1-1.2 $\mathrm{V}$ with a sweep rate of $50 \mathrm{mV} \mathrm{s}^{-1}$. The counter and working electrodes were fed with $100 \mathrm{ml} \mathrm{min}{ }^{-1} \mathrm{H}_{2}$ and 200 $\mathrm{ml} \mathrm{min}{ }^{-1} \mathrm{~N}_{2}$, respectively, at $100 \% \mathrm{RH}$ and 1 bar absolute pressure. The cell temperature was held at $80^{\circ} \mathrm{C}$. The electrochemical active surface area (ECSA) was calculated from the $\mathrm{H}_{2}$ desorption signals in the range of $100-400 \mathrm{mV}$ using $0.21 \mathrm{mC} \mathrm{cm}^{-2}$ [31] as the charge to oxidize one monolayer of hydrogen adsorbed on Pt.

\section{RESULTS AND DISCUSSION}

In the following the results of the prior described experiments will be discussed starting with (i) the investigation of the compatibility of a methanol-water solution with the MEA materials, (ii) the freeze-thaw cycling, and (iii) the possible cold start procedures.

\subsection{Material compatibility with antifreeze}

Prior performing antifreeze tests MEAs were electrochemically characterized at nominal conditions. After this the system was shut down to allow the cell to cool down to $+20^{\circ} \mathrm{C}$ followed by purging the anode and cathode compartments with dry $\mathrm{N}_{2}$ at a flow rate of $500 \mathrm{ml} \mathrm{min}^{-1}$ for $5 \mathrm{~min}$ to remove residual $\mathrm{H}_{2}$ and air. Hereafter the anode and cathode compartments were flooded with the methanol solution. The methanol solution was kept inside the cell for $112 \mathrm{~h}$, after which it was removed by purging the cell with $\mathrm{N}_{2}$ for 5 minutes and DI water for 5-10 min. The nitrogen purging procedure was then repeated a second time to ensure the complete removal of the methanol solution.

In order to compare MEA performance before and after soaking the PEMFC was operated and characterized again after the soaking and cleaning procedure described above at nominal conditions. 
The comparison of the data collected prior and after methanol soaking reveals that the methanol solution does not induce any performance losses. The performance curve at begin-of-test (BoT), i.e. of the pristine MEA, and after soaking in methanol is depicted in Figure 1 (A). An interesting observation here is that the performance after methanol soaking is slightly higher than at BoT. This however may be a result of the increased humidification of the ionomer introduced by the methanolwater solution. This can be seen from the substantial reduction of the impedance (compare Figure 4 (A)) or alternatively also a reduction of Pt oxides by the alcohol is possible. In other words, the lower performance at BoT compared to the performance after soaking in the antifreeze may be due to an incomplete breaking-in procedure.

(A)

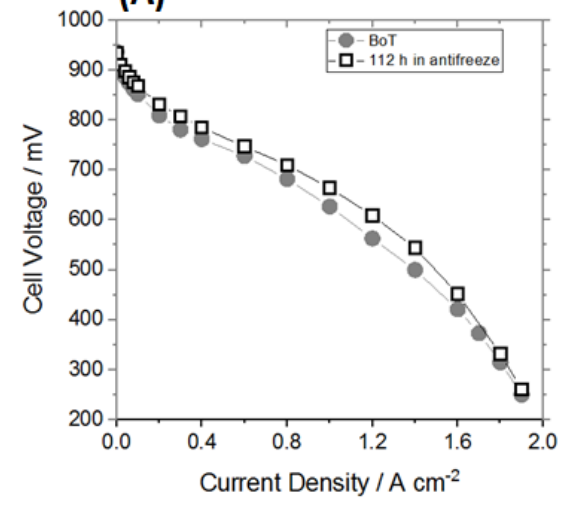

(B)

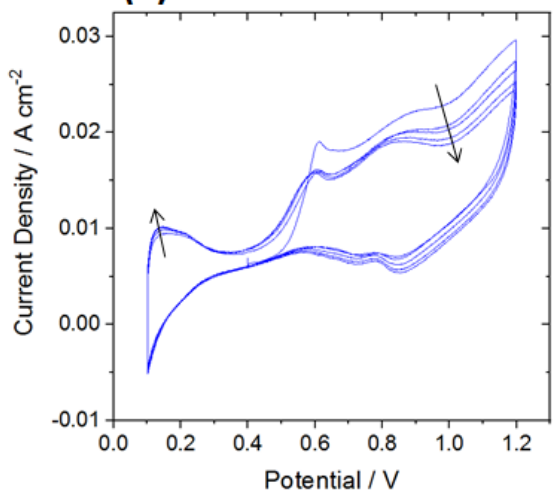

(C)

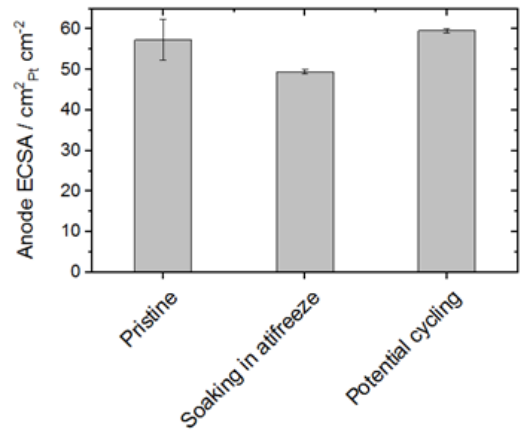

Figure 1: (A) Performance curves of a fresh MEA and a MEA after $112 \mathrm{~h}$ soaking in antifreeze at $20^{\circ} \mathrm{C}$. (B) CV measurement of anode after 112 soaking in antifreeze at $20^{\circ} \mathrm{C}$. (C) Comparison of anode ECSA of pristine MEA, of an MEA after $112 \mathrm{~h}$ soaking in antifreeze and the same MEA after potential cycling up to $1.2 \mathrm{~V}$ to remove contaminants.

After measuring the performance, CVs of the anode and cathode were recorded. In Figure 1 (B) the CV measurement of the anode is shown. It consists of several subsequent cycles, chronology indicated by the black arrows. The peak around $0.6 \mathrm{~V}$ which is observed in the first cycle decreases upon cycling; it is assigned to the desorption of $\mathrm{CO}$ reactively produced due to methanol decomposition on the Pt catalyst [32,33]. While $\mathrm{CO}$ (which occupies Pt sites needed for $\mathrm{H}_{2}$ adsorption) is stripped from the Pt catalyst [34], the $\mathrm{H}_{2}$ desorption signal at 0.1-0.2 V increases. 
The shift of the $\mathrm{CV}$ to positive currents is due to $\mathrm{H}_{2}$ cross-over current which is estimated to be around $8 \mathrm{~mA} \mathrm{~cm}^{-2}$ (@400 mV). This value is high compared to literature values of around $1-2 \mathrm{~mA} \mathrm{~cm}$ ${ }^{2}$, see Ruiu et al. [35]. However, the MEA used in this paper has a particularly thin membrane as shown in the supporting information. The tilt of the $C V$ is due to slight short circuit of the MEA; i.e. the membrane does not act as a perfect electrical insulator. The resistance of the short circuit corresponds to $59 \Omega \mathrm{cm}^{2}$. This value was determined from the slope of the CV's centerline according to Stack-Test Test Module P-10a [36].

In order to quantify the effect of methanol on the anode catalyst the ECSAs of the (i) pristine anode, (ii) the anode after soaking in methanol, (iii) and after subsequent CO stripping were calculated from the $\mathrm{H}_{2}$ desorption signal of $\mathrm{CV}$ measurements. The results are depicted in in Figure 1 (C). Accordingly, the anodic ECSA loss due to soaking in methanol is $12 \%$ which is fully recoverable upon potential cycling at the anode. Since no performance decay was observed due to soaking the MEA in 40 vol\% methanol solution, the $12 \%$ ECSA loss at the anode is considered as negligible. This outcome is in accordance with previous works where the impact of anode ECSA (or Pt loading) on performance has been found to be only minor [37].

The cathode experiences potentials are substantially higher than $0.6 \mathrm{~V}$ during PEMFC operation, hence CO poisoning is not an issue at the cathode.

Regarding membrane or ionomer dissolution, a 40 vol\% methanol concentration is not expected to be an issue as long as cell temperature is below $80^{\circ} \mathrm{C}[38]$.

\subsection{Freeze thaw cycling}

To investigate the effect of the 40 vol\% methanol solution (called antifreeze in the following) on $\mathrm{F} / \mathrm{T}$ cycling and assess its effectiveness as antifreeze for PEMFC in comparison with other conditioning procedures, the following shut-down protocols presented in Figure $2(A),(B)$ and $(C)$ have been applied using the temperature profile depicted in Figure 2 (D): 
- No conditioning: the test described in Figure $2(\mathrm{~A})$ is aimed to measure the performance degradation upon F/T cycling if no conditioning procedure (no dry gas purge and no antifreeze) is applied to the cell. This means that the PEMFC operation was stopped and F/T cycling was immediately started without purging the cell with dry gases. After certain number of F/T cycles (indicated in the figure), PEMFC operation was started again at nominal conditions to test the performance and for electrochemical characterization. For this test the maximum cycling number was set to be 83 which is defined as end-of-test (EoT).

- Dry gas purging: the test outlined in Figure $2(B)$ is intended to evaluate the impact of $F / T$ cycling on MEA performance when the cell was purged with dry gas prior to freezing. After PEMFC operation and electrochemical characterization, the cell was stopped, cooled down to $+40^{\circ} \mathrm{C}$ following a purging of the anode and cathode compartments for 5 min with $500 \mathrm{ml}$ $\min ^{-1}$ dry $N_{2}$ and $1000 \mathrm{ml} \mathrm{min}^{-1}$ dry $N_{2}$, respectively. After this conditioning procedure $\mathrm{F} / \mathrm{T}$ cycling was initiated. The cycling was interrupted after a certain number of $F / T$ cycles (indicated in the figure) to test cell performance and for electrochemical characterization at $80^{\circ} \mathrm{C}$. Then, the conditioning procedure was applied again and F/T cycling was continued. For this test the maximum cycling number was set to be 80 .

- Antifreeze: the test outlined in Figure 2 (C) was dedicated to perform F/T cycling using the antifreeze. The procedure consisted of: (i) stopping cell operation, (ii) cooling down the cell to $+20^{\circ} \mathrm{C}$ and purging anode and cathode for 5 min with $500 \mathrm{ml} \mathrm{min}^{-1} \mathrm{dry} \mathrm{N}_{2}$, and (iii) filling anode and cathode compartments with the antifreeze. After this conditoning protocol the F/T cycling was initiated. For performance testing and electrochamical characterization the $\mathrm{F} / \mathrm{T}$ cycling was interrupted. For that the cell was heated to $+20^{\circ} \mathrm{C}$ and the antifreeze was removed by $\mathrm{N}_{2}$ purging, flushing by DI water ( $5-10 \mathrm{~min}$ ) and a subsequnet purging by dry $\mathrm{N}_{2}$ for 5 min with $500 \mathrm{ml} \mathrm{min-1.} \mathrm{The} \mathrm{maximum} \mathrm{cycling} \mathrm{number} \mathrm{for} \mathrm{this} \mathrm{test} \mathrm{was} \mathrm{set} \mathrm{to} \mathrm{be} 87$. It is noted that this test was repeated (94 cycles) by using $+3^{\circ} \mathrm{C}$ instead of $+20^{\circ} \mathrm{C}$ as maximum temperature during $\mathrm{F} / \mathrm{T}$ cycling (indicated in brackets in Figure $2(\mathrm{C})$ ) in order to reduce 
mechanical stress of the MEA by swelling in the antifreeze, which is less severe at lower temperatures [38].

(A)

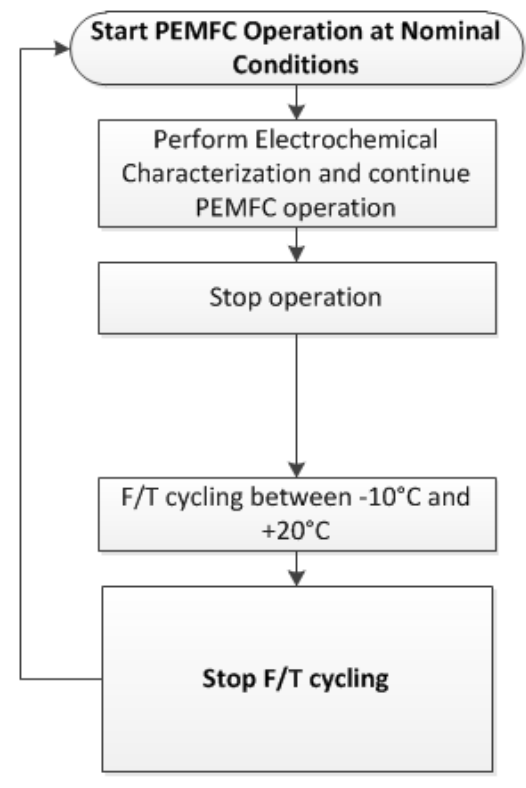

(B)

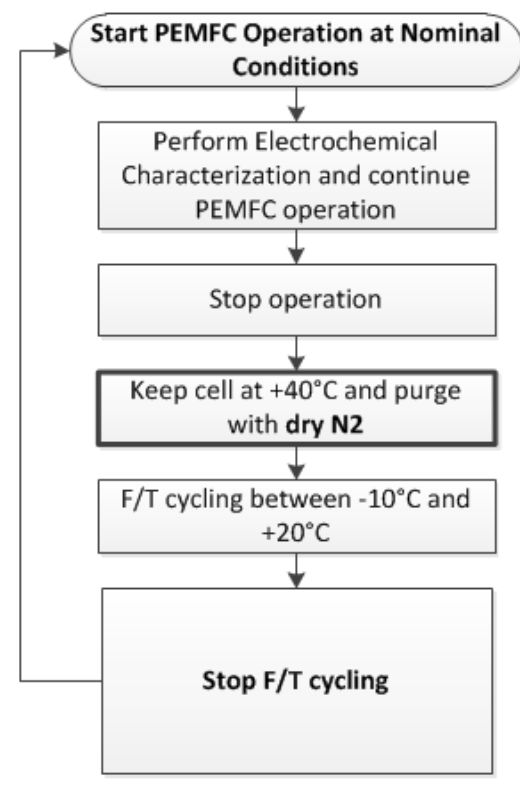

(C)

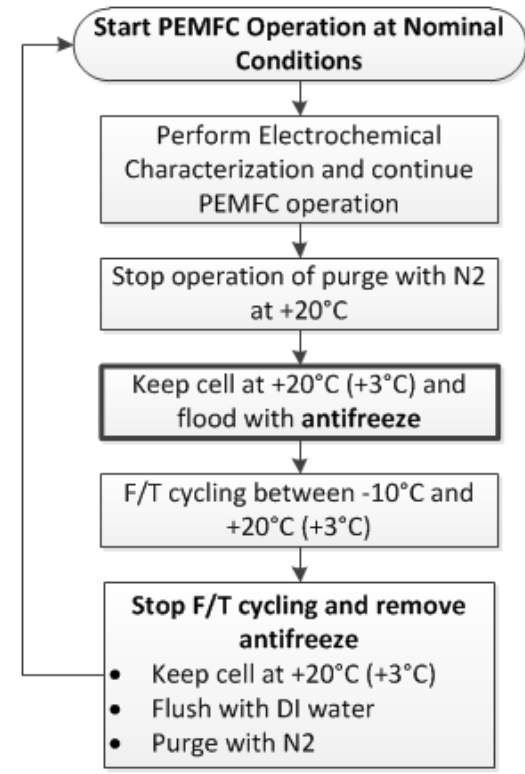

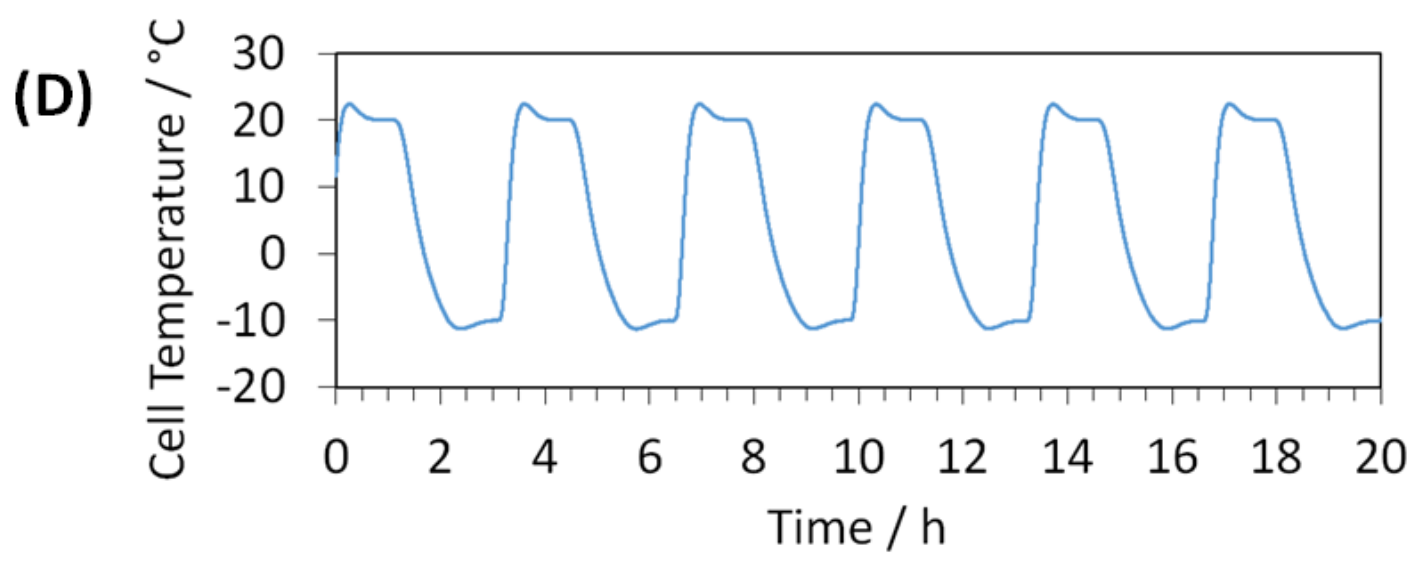

Figure 2: Different protocols applied prior to F/T cycling. (A) The cell was shut down after PEMFC operation at $100 \%$ without a conditioning procedure prior to F/T cycling. (B) The cell was purged with dry N2 prior to F/T cycling. (C) The cell was flooded with 40 vol\% MeOH solution prior to F/T cycling. (D) Cell temperature measured during F/T cycling.

Performance characteristics of the MEAs subject to the three different F/T cycling tests are depicted in Figure $3(A),(B)$, and $(C)$ after the indicated number of cycles. Since the $F / T$ cycling tests were interrupted manually for electrochemical characterization, the number of cycles differs in the 
individual experiments. Performing F/T cycling without a conditioning procedure leads to strong performance losses at current densities $>0.6 \mathrm{~A} \mathrm{~cm}^{-2}$ as observed in Figure 3 (A). The low current density range is only slightly affected by F/T cycling (see insets of Figure 3 ) in accordance with Lee et al. [6] and Cho et al. [27]. After 41 cycles the losses at high current densities are already substantial while after 83 cycles a current density of $1.8 \mathrm{~A} \mathrm{~cm}^{-2}$ could not be reached anymore due to low cell voltage. Similarly, severe performance losses are observed at high current densities in case of dry gas purging prior to F/T cycling shown in Figure 3 (B). The absolute losses, however, are slightly reduced if dry gas purging is used. Moreover, no losses are observed at low current densities (see insets of Figure 3). This is consistent with literature [6] and is expected since there is less ice formation if the cell is dried before cooling to $\mathrm{T}<0^{\circ} \mathrm{C}$. In summary, since high performance losses are observed at high current densities and low performance losses are observed at low current densities, the data clearly suggests that ice formation mainly affects the mass transport properties of the MEA.

These observations are in contrast to the results of $F / T$ cycling using antifreeze in Figure 3 (C); i.e. when using antifreeze the performance losses are virtually eliminated up to a current density of $1.4 \mathrm{~A}$ $\mathrm{cm}^{-2}$ and the losses at higher current densities are strongly reduced. This result is confirmed by the second $\mathrm{F} / \mathrm{T}$ cycling experiment with the antifreeze using $+3^{\circ} \mathrm{C}$ (instead of $+20^{\circ} \mathrm{C}$ ) as maximum temperature during $\mathrm{F} / \mathrm{T}$ cycling (see Figure $1 \mathrm{~S}$ of the supporting information).

The degradation observed in these three tests was quantified by calculating the relative performance losses between BoT and EoT shown in Figure 3 (D). It is noted that that data of the second F/T cycling experiment with the antifreeze using $+3^{\circ} \mathrm{C}$ (instead of $+20^{\circ} \mathrm{C}$ ) as maximum temperature during $\mathrm{F} / \mathrm{T}$ cycling is included for the sake of completeness. For current densities $<0.6 \mathrm{~A} \mathrm{~cm}^{-2}$ the degradation is nearly negligible for all tests. However, if no conditioning is applied or dry gas purging is used as conditioning procedure the performance losses $\Delta p / p$ increase with increasing current density $j$ following a parabolic function $\Delta p / p \propto j^{2}$ (see dashed and dotted curve in Figure 3 (D)). Thereby, dry gas purging has a slight positive effect on mitigation of performance losses. However, it is significantly smaller than in case of the antifreeze. The data of the $F / T$ cycling tests using the 
antifreeze clearly show that no performance decay occurs up to $1.4 \mathrm{Acm}^{-2}$ for cycling in the temperature range -10 to $+20^{\circ} \mathrm{C}$ or even up to $1.6 \mathrm{Acm}^{-2}$ if the maximum cycling temperature is reduced from $+20^{\circ} \mathrm{C}$ to $+3^{\circ} \mathrm{C}$. The data again demonstrate the great advantage of using the antifreeze which fully mitigates performance losses for current densities up to $1.4 \mathrm{Acm}^{-2}$ at which the peak performance is observed. At current densities $>1.4 \mathrm{Acm}^{-2}$ the performance losses increase but are still only half of those without conditioning and with dry gas purging.

According to Cho et al. [27] without methanol as antifreeze a degradation rate of $2.8 \%$ per cycle was measured at $600 \mathrm{mV}$ during $\mathrm{F} / \mathrm{T}$ cycling (15 cycles in total) which is substantially higher than the corresponding values in our study (the observed losses in Figure 3 (D) correspond to $<0.2 \% /$ cycle at 1.2 $\mathrm{Acm}^{-2}$ ). This is likely due to other materials used with different sensitivities to freezing. When using methanol as antifreeze no degradation was detected at $600 \mathrm{mV}$ by the authors being in line with our results.

In other words, if no antifreeze is used and the degradation rate equals roughly $0.25 \% /$ cycle at peak performance (1.4 Acm $\left.{ }^{-2}\right)$. Accordingly, the end-of-life criterion for PEMFC with a performance loss of $10 \%$ is reached already after 40 cycles. This underlines the importance of the antifreeze allowing to reduce the degradation rate down to $0 \% /$ cycle for a broad range of current densities. 


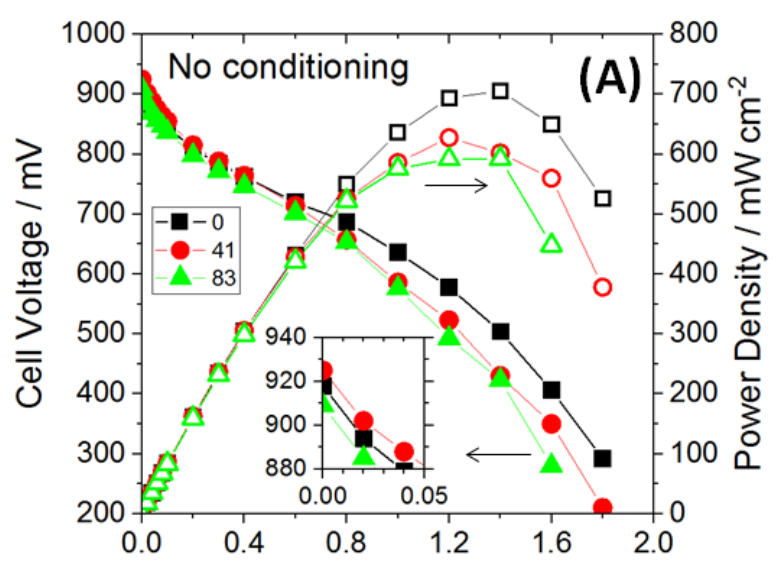

Current Density / $\mathrm{A} \mathrm{cm}^{-2}$

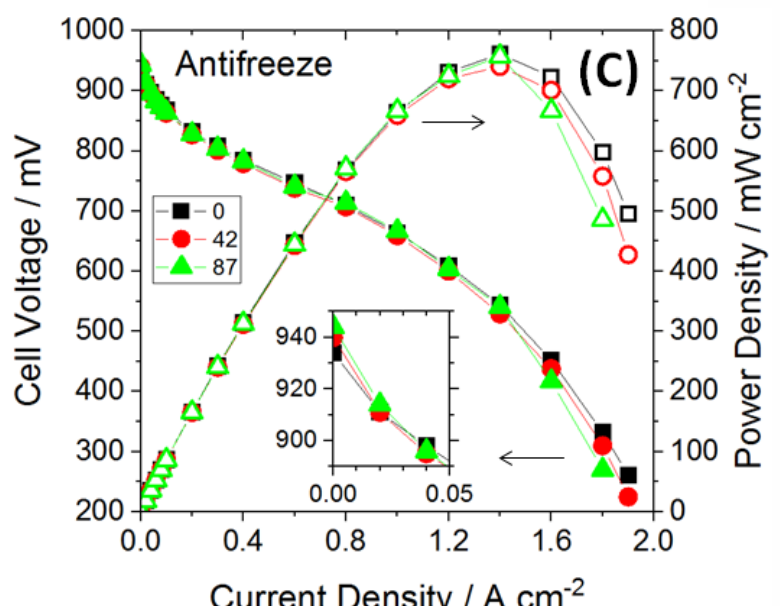

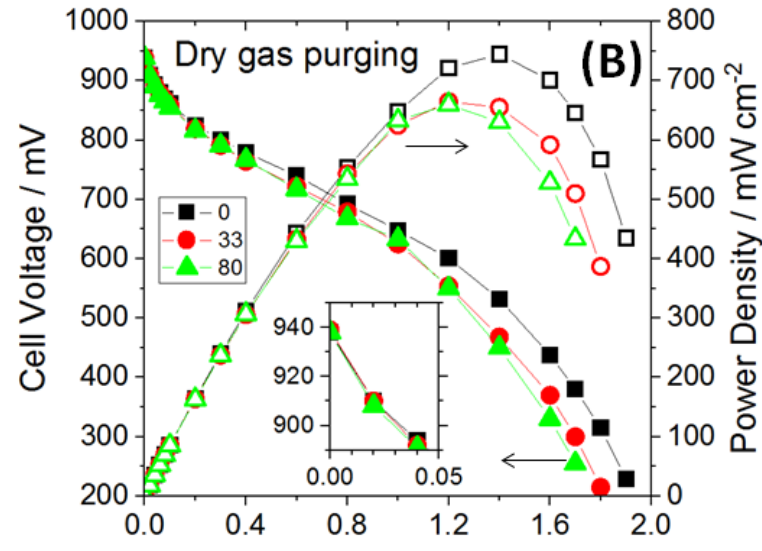

Current Density / $\mathrm{A} \mathrm{cm}^{-2}$

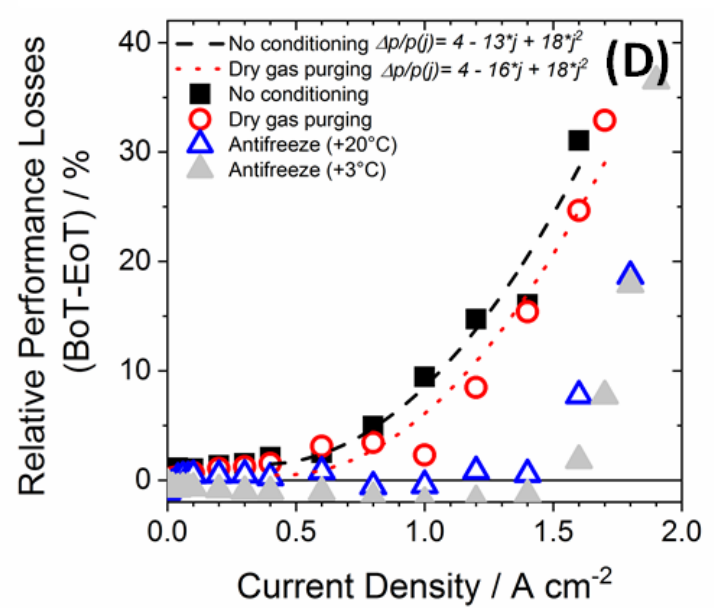

Figure 3: Performance curves measured after the indicated number of F/T cycles. (A) The cell was shut down after PEMFC operation at $100 \%$ without a conditioning procedure prior to F/T cycling. (B) The cell was purged with dry N2 prior to F/T cycling. (C) The cell was flooded with 40 vol\% $\mathrm{MeOH}$-water-solution prior to $\mathrm{F} / \mathrm{T}$ cycling using $+20^{\circ} \mathrm{C}$ as maximum temperature. The insets are enlargements of the OCV regions. (D) Relative performance losses of the different F/T cycling tests. In addition the result of the $\mathrm{F} / \mathrm{T}$ cycling using antifreeze and a reduced temperature range $\left(-10^{\circ} \mathrm{C}\right.$ to $\left.+3^{\circ} \mathrm{C}\right)$ is shown. The dashed and dotted curves are parabolic fits for current densities $\mathrm{j}>0.4 \mathrm{Acm}^{-2}$ as indicated in the figure.

\subsection{Degradation analysis}

Electrochemical impedance spectroscopy (EIS) and cyclic voltammetry (CV) were used as electrochemical characterization methods in order to deepen the understanding of the degradation processes occurring during the F/T cycling tests. Additionally scanning electron microscopy was used to investigate structure changes due to $\mathrm{F} / \mathrm{T}$ cycling. 


\subsubsection{Electrochemical Impedance Spectroscopy}

EIS spectra of a pristine MEA as well as MEAs after F/T cycling without conditioning, with dry gas purging and with using the antifreeze are depicted in Figure $4(\mathrm{~A})$. For a better clarity of presentation a bar graph showing the low frequency (LFR) and high frequency resistance (HFR) defined as the corresponding intercepts of the EIS spectrum with the real axis is provided as an inset. The results clearly show increased total impedance (LFR) after F/T cycling without conditioning compared to the pristine MEA. Thereby, both arcs of the spectrum increase which can be assigned (based on the frequencies indicated in the figure for the $\mathrm{F} / \mathrm{T}$ cycling tests without conditioning) to an increase of both the charge transfer as a minor effect and mass transport resistances as the major effect [39]. Hence, the results are in agreement with the observed performance losses at high current densities in Figure 3. Reasons for the increased impedance can be damage of the catalyst layer or GDL due to freezing of captured water [6]. The high frequency intercept (HFR) of the EIS spectra revels that no changes of the ohmic resistance are observed in all the studied cases.

The EIS spectrum after using dry gas purging exhibits only minor changes compared to the pristine one; in particular, not increase of LFR and HFR is observed, which underlines the positive effect of water removal before freezing.

On the other hand, the spectrum after F/T cycling using the antifreeze shows a reduction of the total impedance (LFR) compared to the pristine MEA. This applies to both arcs, i.e. the mass transport and the charge transfer resistances are affected. A possible reason for this counterintuitive observation could the improved hydration of the ionomer due to soaking in the methanol-water solution leading to higher ionic conductivity or due to reduction of residual Pt oxides. This hypothesis is supported by the EIS spectrum of a pristine MEA after soaking in DI-water without methanol (grey triangles) which also exhibits a substantially reduced impedance compared to the pristine one (black squares). Moreover, the performance curve of the MEA after soaking in the antifreeze also exhibits slightly higher performance than the pristine one (compare Figure $1(A))$. 

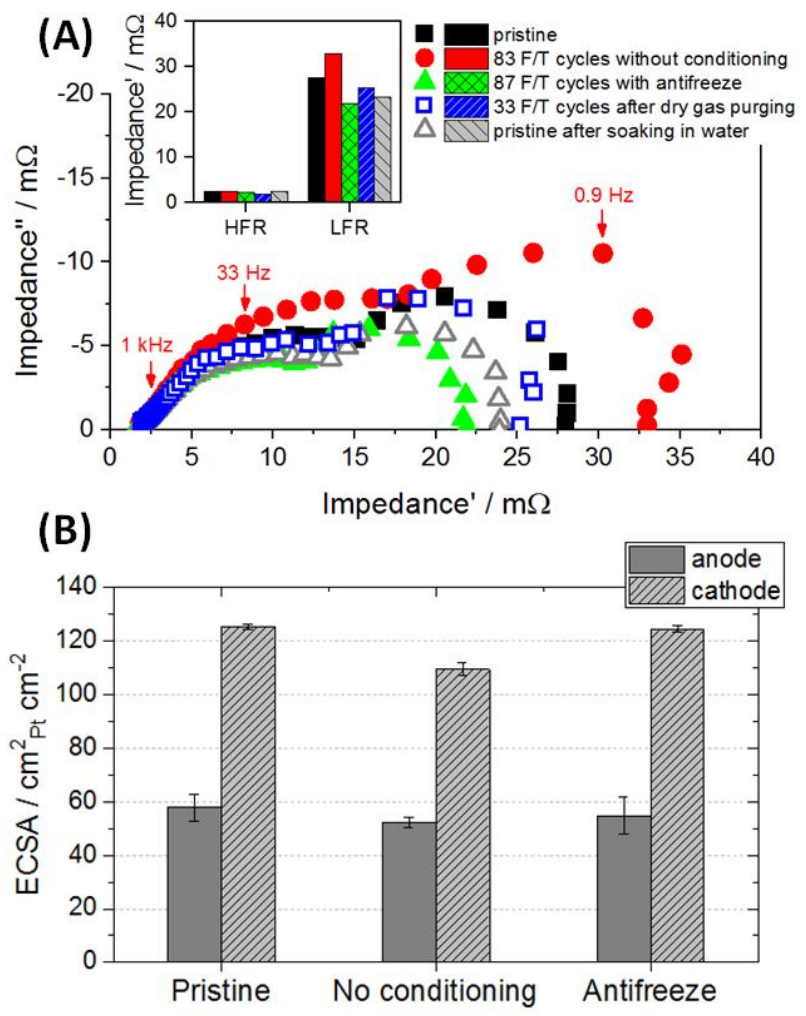

Figure 4: (A) Nyquist presentation of EIS spectra of a pristine MEA and MEAs after F/T cycling with and without antifreeze as well as after dry gas purging measured at $1 \mathrm{Acm}^{-2}$. For comparison a spectrum of a MEA after soaking in pure water is shown. The inset shows the high frequency (HFR) and low frequency resistance (LFR) defined as the intercepts of the EIS spectra with the real axis. The frequencies indicated by the arrows in the EIS spectrum after F/T cycling without conditioning (red bullets) are to support assignment of the observed features. (B) Anode and cathode ECSA of a pristine MEA and ECSA measured of MEAs after F/T cycling with and without antifreeze determined from the H2 desorption peak area of CV measurements performed at EoT (i.e. after 83 and 87 cycles, respectively).

\subsubsection{Cyclic Voltammetry}

The impact of F/T cycling on the electrodes was evaluate by calculating the ECSAs from the CV measurements of the pristine MEA (after breaking-in and characterization) as well as after F/T cycling without conditioning and with using the antifreeze. The calculated anode and cathode ECSAs are compared in Figure 4 (B). A slight decrease of anode ECSA is observed which, however, is not expected to affect cell performance [29]. 
On the cathode side an ECSA loss of $13 \%$ is determined after F/T cycling without conditioning which is significant compared to the minor loss of $\sim 1 \%$ after F/T cycling using the antifreeze. Therefore, the antifreeze seems to mitigate cathodic ECSA loss. Without the antifreeze the cathodic ECSA loss is proposed to be caused by formation of ice precipitates between the catalyst and the ionomer $[40,41]$. This slight cathodic ECSA loss may be responsible for the minor performance loss observed in Figure $3(A)$ in the activation current density range of the performance curves.

\subsubsection{Electron Microscopy}

After the cycling tests, the MEAs were disassembled the electrodes were analyzed by SEM. After removing the $\mathrm{GDL}$ from the $\mathrm{CL}$, the $\mathrm{CL}$ areas positioned under the land of the flow filed were covered by MPL residues. Therefore, only electrode areas located under the channels were analyzed; these areas are more prone to degradation during $\mathrm{F} / \mathrm{T}$ cycling than areas under the land where removal of the water is more effective [7,42]. SEM images of the MEA cross-sections (see Figure $2 \mathrm{~S}$ of the supporting information) do not indicate delamination of the $\mathrm{CL}$ from the membrane that was reported in literature $[42,43]$. The electrode surfaces (see Figure 35 in the supporting information), on the other hand, exhibit cracks in the range of tens of microns which density depend on the applied testing protocol. The crack density was manually quantified for a pristine MEA (after breaking-in) and for MEAs after F/T cycling without conditioning and with using the antifreeze as shown in Figure 5 (A). Additionally, a MEA after F/T cycling using antifreeze, but with reduced maximum cycling temperature $\left(+3^{\circ} \mathrm{C}\right.$ instead of $\left.20^{\circ} \mathrm{C}\right)$ was investigated. Apparently, crack density is highest if the antifreeze is used in combination with cycling up to $+20^{\circ} \mathrm{C}$, likely due mechanical stress caused by swelling [38]. Reducing maximum cycling temperature to $+3^{\circ} \mathrm{C}$ leads to substantial reduction of crack density supporting the idea of reduction of mechanical stress by reducing cycling temperature. Since using the antifreeze has positive effect on MEA durability during F/T cycling, the increased crack density at the electrodes after these tests do not seem to be detrimental which is consistent with a study by Guo and Qi [44] who also observed electrode cracking and related ECSA loss due to ice formation which, however, did not affect cell performance significantly. 
It has to be mentioned that in case of the MEA that was cycled up to $+20^{\circ} \mathrm{C}$ using the antifreeze a failure suddenly occurred after the EoT characterization. This failure happened once and could not be repeated in a second test (reduced upper cycling temperature). Nevertheless, since this failure is critical, it is needs to be described here for sake of completeness. Specifically, a serious decrease of cell performance was observed associated with a strong increase of $\mathrm{H}_{2}$ cross over current density to $\sim 0.1 \mathrm{Acm}^{-2}$ which is $10 \mathrm{x}$ higher than the value of a pristine MEA. According to the IR thermography image of this MEA shown in Figure 5 (B), which was performed after disassembling the PEMFC cell and installing the MEA in a dedicated test cell (one side of the MEA was exposed to $\mathrm{H}_{2}$ and the other to ambient air while the temperature distribution was monitored using a Seek Thermal compact infrared camera) there is a local hot spot close the corner of the active area. Evidently, the MEA exhibits a local membrane defect (pinhole or crack). Since chemical membrane degradation can be ruled out, mechanical stress seems to be the most likely explanation of this failure. It is noted that in the separate $\mathrm{F} / \mathrm{T}$ cycling test with the antifreeze and maximum cycling temperature reduced to $+3^{\circ} \mathrm{C}$ (i.e. with less swelling), this phenomenon could not be reproduced. However, the lack of such a sudden error cannot be taken as evidence that this approach is sufficient to mitigate membrane failure due to mechanical stress. Nevertheless, when exposing the cell to the antifreeze limiting mechanical stress by limiting the maximum cell temperature to $+3^{\circ} \mathrm{C}$ has an unambiguously positive effect as shown by the low crack density of the corresponding electrode in Figure 5 (A). 

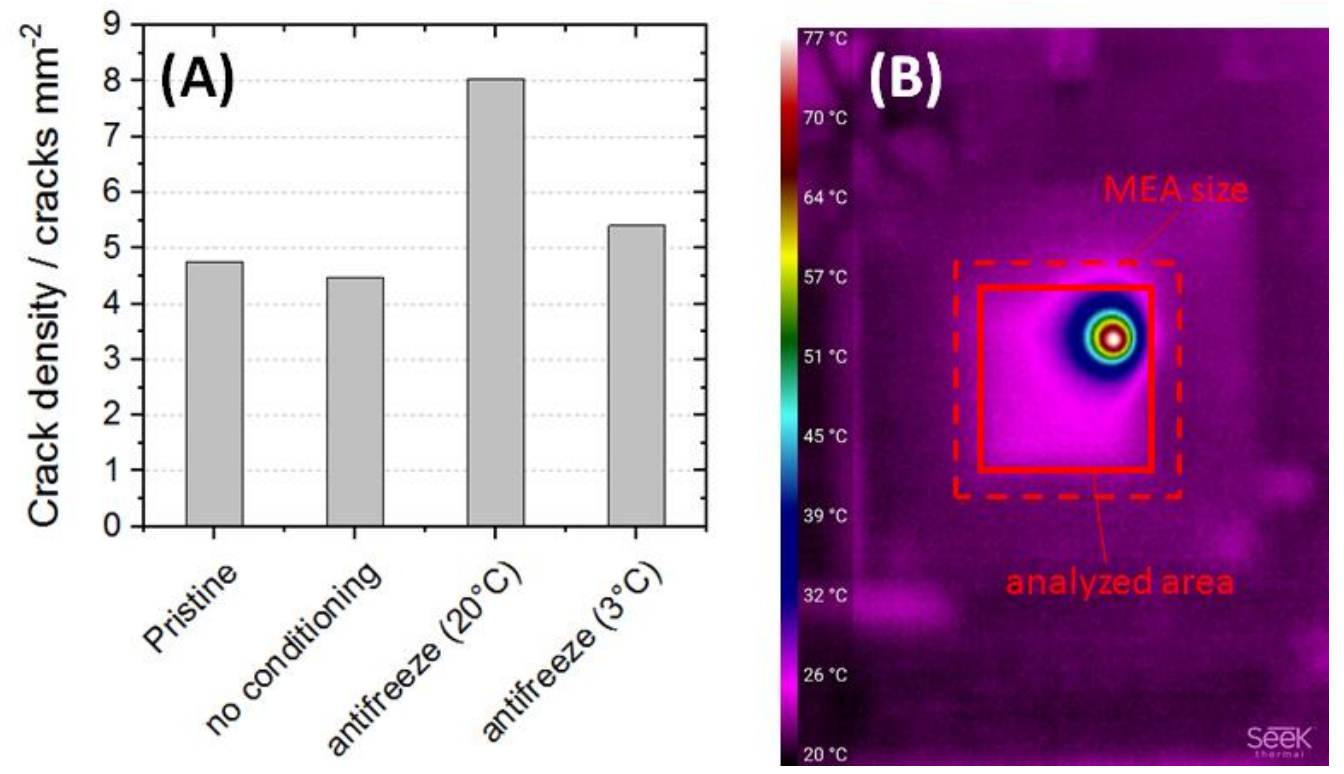

Figure 5: (A) Crack density of the cathode of a pristine MEA as well as MEAs after F/T cycling. "no conditioning" means with PEMFC operation has been stopped without any conditioning prior to F/T cycling. "antifreeze $\left(20^{\circ} \mathrm{C}\right)^{\prime}$ means the cell was flooded with the antifreeze during standard $\mathrm{F} / \mathrm{T}$ cycling (from $-10^{\circ} \mathrm{C}$ to $\left.+20^{\circ} \mathrm{C}\right)$. "antifreeze $\left(3^{\circ} \mathrm{C}\right)$ " means the cell was flooded with the antifreeze during $\mathrm{F} / \mathrm{T}$ cycling, but the maximum cycling temperature was reduced to $+3^{\circ} \mathrm{C}$. (B) IR thermography image of the MEA after $87 \mathrm{~F} / \mathrm{T}$ cycles (from $-10^{\circ} \mathrm{C}$ to $+20^{\circ} \mathrm{C}$ ) with the antifreeze. The solid and the dashed squared indicate the analyzed area $\left(40 \times 40 \mathrm{~mm}^{2}\right)$ and the MEA active area $\left(50 \times 50 \mathrm{~mm}^{2}\right)$, respectively.

\subsection{Cold start}

After proving the methanol-water solutions as suitable antifreeze, different cold start strategies have been explored in order to evaluate whether a cold start is possible when using the antifreeze. In particular, the following three approaches have been pursued: (i) cold start in DMFC mode, (ii) cold start in PEMFC mode using antifreeze, and (iii) Cold start in PEMFC mode with dry gas conditioning as outlined in Figure 6. 
(A)

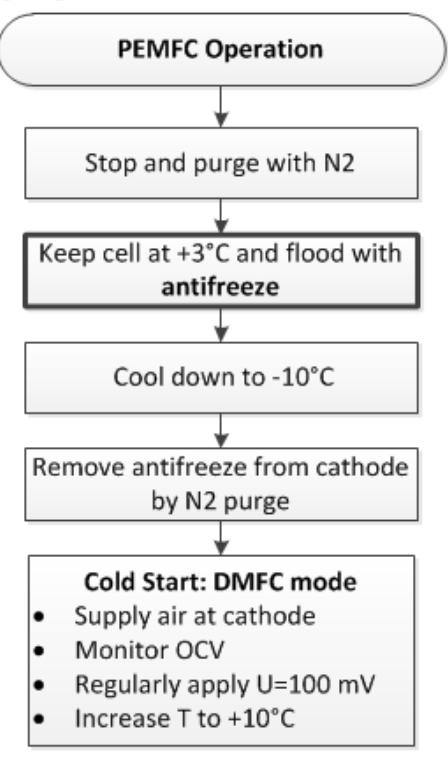

(B)

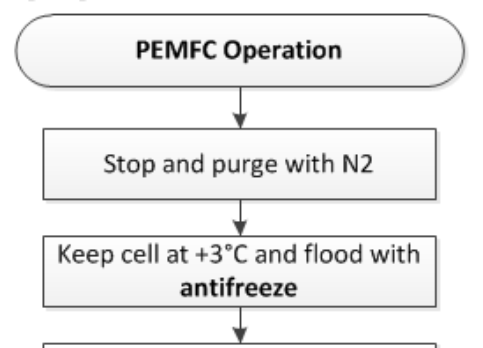

Cool down to $-10^{\circ} \mathrm{C}$

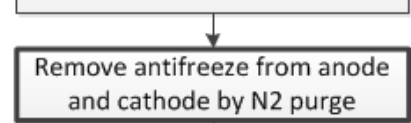
and cathode by N2 purge

Cold Start: PEMFC mode

- Supply H2/air

- Monitor OCV

- Apply $\mathrm{U}=600 \mathrm{mV}$

- Increase $\mathrm{T}$ to $+20^{\circ} \mathrm{C}$
(C)

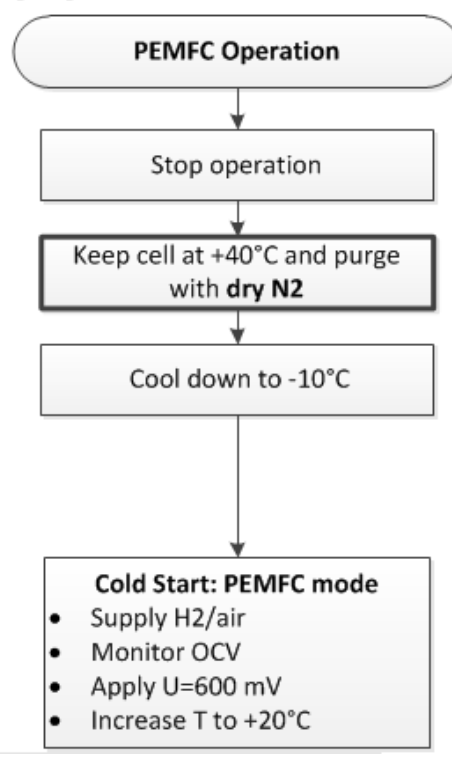

Figure 6: Different tested cold shut down and start up protocols. (A) Start up at $-10^{\circ} \mathrm{C}$ in DMFC mode (antifreeze at anode and air at cathode). (B) Start up at $-10^{\circ} \mathrm{C}$ in PEMFC mode ( $\mathrm{H} 2$ at anode and air at cathode) after soaking the cell in antifreeze. (C) Start up at $-10^{\circ} \mathrm{C}$ in PEMFC mode without prior soaking the cell in antifreeze.

\subsubsection{Cold start in DMFC mode}

Since methanol is available in the cell, one option to perform a cold start is using the methanol to operate the cell in direct methanol fuel cell (DMFC) mode, i.e. using methanol as a fuel. It is noted that this test was performed using a standard Pt/Pt MEA as well as a PtRu/Pt MEA. Since methanol is converted to strongly adsorbed $\mathrm{CO}$ on a Pt anode and acts as catalyst poison, the PtRu anode was chosen as an alternative to allow the formation of desorbing $\mathrm{CO}_{2}$ as final reaction product of the methanol oxidation [45]. After PEMFC operation in nominal conditions, the cell was stopped and anode and cathode compartments were purged with dry $\mathrm{N}_{2}$ before filling them by the antifreeze at $+3^{\circ} \mathrm{C}$ as already described in the context of Figure 2. Subsequently, the cell was cooled down to $10^{\circ} \mathrm{C}$. After removing the antifreeze from the cathode compartment by $\mathrm{N}_{2}$ purging at $-10^{\circ} \mathrm{C}$, an air flow of $1000 \mathrm{ml} \mathrm{min}{ }^{-1}$ was applied. Eventually, the cell temperature was continuously increased to 
$+10^{\circ} \mathrm{C}$ while monitoring $\mathrm{OCV}$ (to determine the maximum cell potential) and applying $100 \mathrm{mV}$ load in potentiostatic mode.

The temperature, voltage and current profiles of the three cold start procedures are plotted in Figure 7. During the cold start in DMFC mode using the PtRu/Pt MEA (Figure 7 (A)) a low OCV of $210 \mathrm{mV}$ was monitored at $-10^{\circ} \mathrm{C}$ (using Pt/Pt MEA OCV was only $130 \mathrm{mV}$ ) which increased only slightly with increasing cell temperature to $+20^{\circ} \mathrm{C}$. The current measured after regularly applying a voltage of 100 $\mathrm{mV}$ was negligibly low with values $<0.1 \mathrm{~A}\left(<4 \mathrm{~mA} \mathrm{~cm}{ }^{-2}\right)$. To test if additional removal of residual antifreeze from the cathode can increase cell performance the cathode was flushed with DI-water at $t=70-80 \mathrm{~min}$ as indicated in the figure. However, no substantial increase of OCV and current at 100 $\mathrm{mV}$ was observed (see test time $>90 \mathrm{~min}$ ). The low OCV and negligible current at $100 \mathrm{mV}$ in DMFC mode are explained by the fact that the event though PtRu was used at the anode, the MEA is designed for $\mathrm{H}_{2}$ /air operation. This means, it has a low anodic Pt loading around $0.1 \mathrm{mg}_{\mathrm{Pt}} \mathrm{cm}^{-2}$ and a thin membrane with a thickness of $<20 \mu \mathrm{m}$ (determined by SEM). Typical DMFC MEAs $[46,47]$, on the other hand, have substantially higher anode loading (e.g. $4 \mathrm{mg}_{\mathrm{PGM}} \mathrm{cm}^{-2}$ ) to handle to poor methanol oxidation kinetics and much thicker membranes (e.g. $180 \mu \mathrm{m}$ ) to mitigate methanol cross over. In other words, the used MEA exhibited substantial activation losses regarding methanol oxidation and dramatic methanol cross over from the anode to the cathode resulting in mixed potential which additionally lowers cell voltage and does not allow DMFC operation $[48,49]$. Hence, the strategy to realize a cold start in DMFC mode is not preferred. 

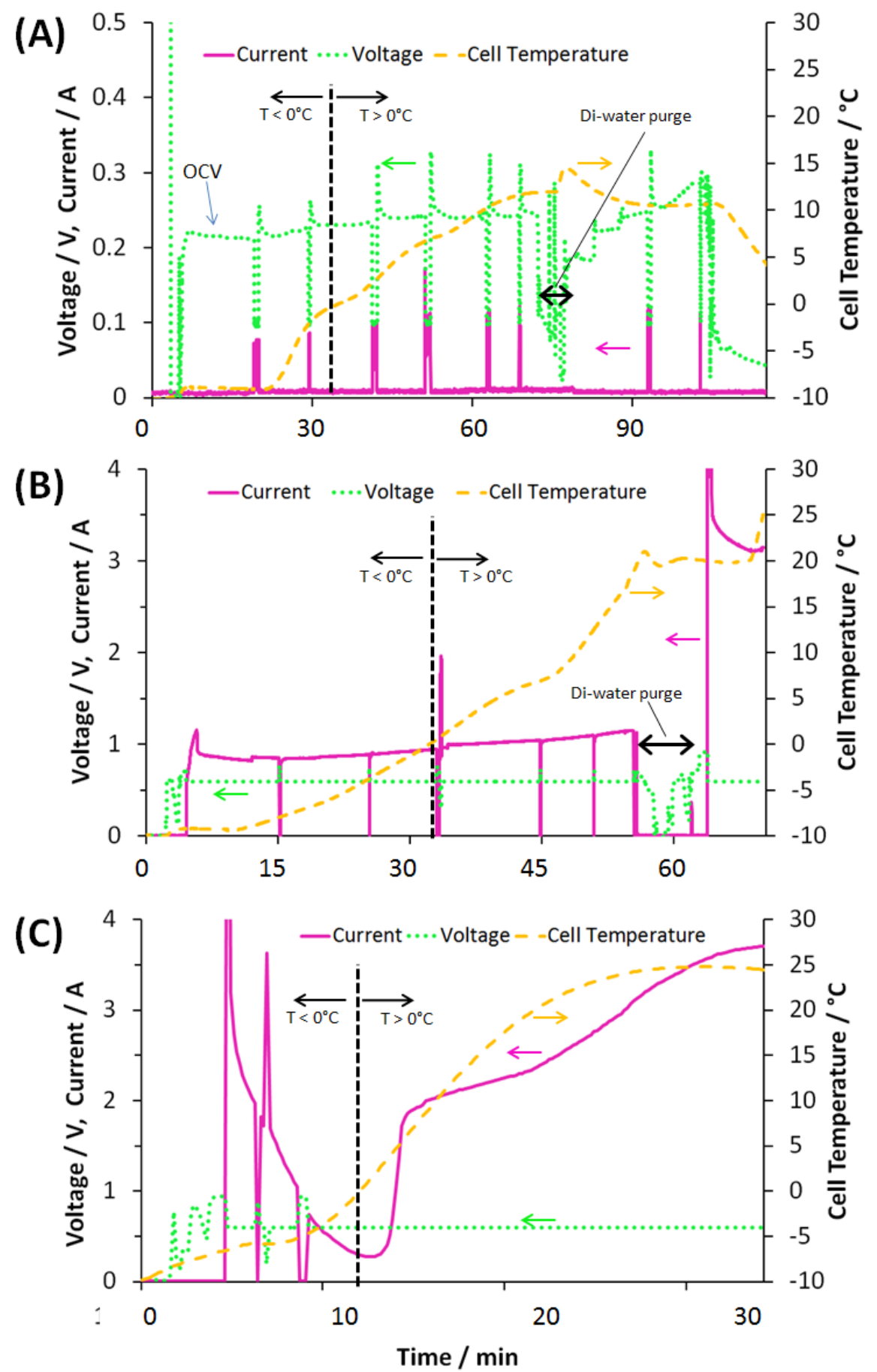

Figure 7: Voltage, current and cell temperature versus operation time during cold start. (A) Cold start in DMFC mode. The cell voltage at $200-300 \mathrm{mV}$ corresponds to $\mathrm{OCV}$. Voltage has been set regularly to $100 \mathrm{mV}$ to monitor current production. (B) Cold start in PEMFC mode after soaking the cell (PtRu/Pt MEA) in antifreeze. Cell voltage was set to $600 \mathrm{mV}$. (C) Cold start in PEMFC mode without soaking the cell in antifreeze. Cell voltage was set to $600 \mathrm{mV}$. The corresponding test protocols are provided in Figure 6. The black dashed lines indicate the sub-zero temperature regime. 


\subsubsection{Cold start in PEMFC mode using antifreeze}

Before performing cold start in PEMFC using the antifreeze, (i) the PEMFC operation was stopped, (ii) the anode and cathode compartments were purged by $\mathrm{N}_{2}$, and (iii) the cell was filled with the antifreeze at $+3^{\circ} \mathrm{C}$, before cooling down to $-10^{\circ} \mathrm{C}$. As next step, the antifreeze was removed from the anode and cathode by $\mathrm{N}_{2}$ purging, before feeding them with $226 \mathrm{ml} / \mathrm{min}$ dry $\mathrm{H}_{2}$ and $624 \mathrm{ml} / \mathrm{min}$ dry air, respectively. The temperature was continuously increased up to $+20^{\circ} \mathrm{C}$ using the external thermostat while monitoring OCV and applying $600 \mathrm{mV}$ load in potentiostatic mode.

The cold start in PEMFC mode after using the antifreeze is shown in Figure 7 (B). At $-10^{\circ} \mathrm{C}$ a OCV of $715 \mathrm{mV}$ was measured. When applying a load of $600 \mathrm{mV}$ a current of approximately $1 \mathrm{~A}\left(40 \mathrm{~mA} \mathrm{~cm} \mathrm{~cm}^{-2}\right)$ is recorded which is an order of magnitude higher than the one measured during DMFC cold start. A slight increase of performance is observed until reaching $0^{\circ} \mathrm{C}$ and ongoing after heating to $+20^{\circ} \mathrm{C}$ likely due to increased reaction kinetics. Noteworthy, there is no drop in the current value below $0^{\circ} \mathrm{C}$ indicative for blockage of gas supply by ice formation, which shows that the methanol content is sufficient to avoid ice formation until $0^{\circ} \mathrm{C}$ is reached. To achieve a substantial increase of performance (increasing current from $1 \mathrm{~A}$ to $3 \mathrm{~A}$ at $600 \mathrm{mV}$ cell voltage) it is necessary to flush the cell with DI-water (see voltage fluctuation indicated in the figure at around $t=60 \mathrm{~min}$ ) to further remove residual methanol which lowers cell voltage by causing mixed potentials at the cathode.

The current of $3 \mathrm{~A}$ at $600 \mathrm{mV}$ measured at the end of the test in Figure 7 (B) is comparable with the current measured after cold start without prior flooding the cell with the antifreeze as shown in Figure 7 (C).

\subsubsection{Cold start in PEMFC mode with dry gas conditioning}

Before cooling the cell to $-10^{\circ} \mathrm{C}$, anode and cathode compartments were purged by dry $\mathrm{N}_{2}$ at $+40^{\circ} \mathrm{C}$ as described in Section 3.2. After keeping the cell at $-10^{\circ} \mathrm{C}$ for $>1 \mathrm{~h}$, anode and cathode were fed with 
$226 \mathrm{ml} / \mathrm{min}$ dry $\mathrm{H}_{2}$ and $624 \mathrm{ml} / \mathrm{min}$ dry air, respectively. The cell temperature was continuously increased up to $+20^{\circ} \mathrm{C}$ while monitoring $\mathrm{OCV}$ and applying $600 \mathrm{mV}$ load in potentiostatic mode.

After starting the cell at $-10^{\circ} \mathrm{C}$ without prior soaking in the antifreeze in Figure 7 (C), a strong current peak (9.5 A at $600 \mathrm{mV}$ ) is observed in Figure 7 (C) which, however, rapidly drops to $3 \mathrm{~A}$ followed by a continuous decrease to values $\ll 1 \mathrm{~A}$. The decrease of the current continues until cell temperature exceeds $0^{\circ} \mathrm{C}$. Consequently, the current decrease at $\mathrm{T}<0^{\circ} \mathrm{C}$ is due to icing of the cathode that extends with time due to produced water during the operation and leads to blockage of gas supply [14]. After cell temperature exceeds $0^{\circ} \mathrm{C}$, a strong increase of the current up to $2 \mathrm{~A}$ occurs; at $20-25$ ${ }^{\circ} \mathrm{C}$ the current equals $3-3.5 \mathrm{~A}$. Up to $50^{\circ} \mathrm{C}$ the current remains below $7 \mathrm{~A}$ independent of humidification and gas pressure; in the temperature window $50-60^{\circ} \mathrm{C}$ the cell performance suddenly increases to $25 \mathrm{~A}\left(1 \mathrm{~A} \mathrm{~cm}^{-2}\right)$ at $600 \mathrm{mV}$ which is close to maximum performance (see Figure $4 S$ in the supporting information).

Even though the current measured in PEMFC at $600 \mathrm{mV}$ cell voltage at $\mathrm{T}>0^{\circ} \mathrm{C}$ is higher if the antifreeze is not used, at temperatures $\mathrm{T}<0^{\circ} \mathrm{C}$ continues PEMFC operation is not possible without residual methanol (due to using antifreeze) inside the cell that prevents icing.

It is noted that the much longer time to reach $+20^{\circ} \mathrm{C}$ in Figure 7 (B) compared to Figure 7 (C) is due to a lower heating power of the potentiostat used in Figure 7 (B) which was first set to $+10^{\circ} \mathrm{C}$ and then to $+20^{\circ} \mathrm{C}$ in a next step; in Figure 7 (C) the target temperature was set to $+20^{\circ} \mathrm{C}$ from the beginning.

\subsubsection{Assessment of cold start using antifreeze}

Generally, in an automotive stack the successful cold start can be realized if heating above $0^{\circ} \mathrm{C}$ occurs faster than the icing of the product water [50]. This depends on cell performance during cold start (it is noted that heat dissipation due to direct oxidation of residual methanol could not be evidenced as shown in Figure $5 \mathrm{~S}$ in the supporting information). Hence, whether the cell performance measured in Figure 7 (B) after soaking the MEA in the antifreeze is sufficient to perform a realistic cold start needs 
to be tested at the stack level. Moreover, if a successful cold start is possible, it is expected that residual methanol is removed from the cell due to evaporation at higher temperature and by drag with product water. Accordingly, the studied antifreeze would be considered as suitable not only to prevent degradation during $\mathrm{F} / \mathrm{T}$ cycling but also suitable to perform a cold start.

The presented results have been performed in a single cell which areal mass density ( $\sim$ several tens $g$ $\left.\mathrm{cm}^{-2}\right)$ is significantly higher than the areal mass density of a stack $\left(\sim 1 \mathrm{~g} \mathrm{~cm}^{-2}\right)$; i.e. the cooling capacity of the single cell is at least one order of magnitude higher than the cooling capacity of the stack. Hence a realistic cold start cannot be studied in the single cell.

However, the starting values with the antifreeze are around $40 \mathrm{~mA} \mathrm{~cm}{ }^{-2}$ in single cell (see Figure 7 (B)). Successful cold start-up tests according to targets of U.S. Department of Energy ( $<30 \mathrm{~s}$ to $50 \%$ power)[51] carried out in a stack by using a conventional start-up procedure (drying with $\mathrm{N}_{2}$ before freezing) have shown $80-120 \mathrm{~mA} \mathrm{~cm}^{-2}$ as starting current density (not shown in this paper). The values with the antifreeze are clearly lower than those obtained without using the antifreeze, but they are still of the same order of magnitude. Therefore it is not clear from today's point of view what start-up time can be achieved with the antifreeze in the stack.

\section{CONCLUSIONS}

In this work a methanol-water solution is investigated as antifreeze for polymer electrolyte membrane fuel cell at the single cell level; a methanol concentration of 40 vol\% was selected to allow freezing down to $-30^{\circ} \mathrm{C}$ required by automotive fuel cells. The results clearly show that using the antifreeze during freeze-thaw cycling strongly reduces performance degradation as compared to freeze-thaw cycling tests without using antifreeze or conditioning by purging the cell with dry gases before freezing. Specifically, performance degradation up to current densities of $1.4 \mathrm{~A} \mathrm{~cm}^{-2}$ (peak performance) is fully eliminated by the antifreeze. Moreover cold start after using the antifreeze was tested revealing that residual antifreeze allows continuous fuel cell operation at sub-zero 
temperatures which is not possible without the antifreeze due to freezing of product water and blockage of gas supply. Residual methanol, on the other hand, reduces cell performance at $\mathrm{T}>0^{\circ} \mathrm{C}$ due to mixed cathode potentials. Therefore, the capability of the antifreeze to be suitable to perform a realistic cold start needs to be tested at the stack level.

\section{Acknowledgements}

This project has received funding from the Fuel Cells and Hydrogen 2 Joint Undertaking under grant agreement No 735969 (INN-Balance). This Joint Undertaking receives support from the European Union's Horizon 2020 research and innovation programme, Hydrogen Europe and Hydrogen Europe research. The authors thank Dr. Schwan Hosseiny for proof-reading, Dr. Jens Mitzel for fruitful discussion, Siegfried Graf for setting up the fuel cell test station for freezing experiments and the antifreeze loop, and Ina Plock for performing the SEM measurements. Moreover the authors thank EWII Fuel Cells A/S for providing customized MEAs for the tests.

\section{References}

[1] T. Zhang, P. Wang, H. Chen, P. Pei, A review of automotive proton exchange membrane fuel cell degradation under start-stop operating condition, Applied Energy. 223 (2018) 249-262. doi:https://doi.org/10.1016/j.apenergy.2018.04.049.

[2] A.A. Amamou, S. Kelouwani, L. Boulon, K. Agbossou, A Comprehensive Review of Solutions and Strategies for Cold Start of Automotive Proton Exchange Membrane Fuel Cells, IEEE Access. 4 (2016) 4989-5002. doi:10.1109/access.2016.2597058.

[3] T.A. Zawodzinski, J. Davey, J. Valerio, S. Gottesfeld, The water content dependence of electro-osmotic drag in proton-conducting polymer electrolytes, Electrochimica Acta. 40 (1995) 297302.

[4] D.G. Sanchez, T. Ruiu, K.A. Friedrich, J. Sanchez-Monreal, M. Vera, Analysis of the Influence of Temperature and Gas Humidity on the Performance Stability of Polymer Electrolyte Membrane Fuel Cells, J. Electrochem. Soc. 163 (2016) F150-F159.

[5] D.G. Sanchez, T. Ruiu, I. Biswas, M. Schulze, S. Helmly, K.A. Friedrich, Local impact of humidification on degradation in polymer electrolyte fuel cells, Journal of Power Sources. 352 (2017) 42-55. doi:10.1016/j.jpowsour.2017.03.057. 
[6] Y. Lee, B. Kim, Y. Kim, X. Li, Effects of a microporous layer on the performance degradation of proton exchange membrane fuel cells through repetitive freezing, Journal of Power Sources. 196 (2011) 1940-1947. doi:10.1016/j.jpowsour.2010.10.028.

[7] Y. Tabe, M. Saito, K. Fukui, T. Chikahisa, Cold start characteristics and freezing mechanism dependence on start-up temperature in a polymer electrolyte membrane fuel cell, Journal of Power Sources. 208 (2012) 366-373. doi:10.1016/j.jpowsour.2012.02.052.

[8] J. Park, H. Oh, T. Ha, Y.I. Lee, K. Min, A review of the gas diffusion layer in proton exchange membrane fuel cells: Durability and degradation, Applied Energy. 155 (2015) 866-880. doi:https://doi.org/10.1016/j.apenergy.2015.06.068.

[9] A. Amamou, M. Kandidayeni, L. Boulon, S. Kelouwani, Real time adaptive efficient cold start strategy for proton exchange membrane fuel cells, Applied Energy. 216 (2018) 21-30. doi:https://doi.org/10.1016/j.apenergy.2018.02.071.

[10] J. Ko, W.-G. Kim, Y.-D. Lim, H. Ju, Improving the cold-start capability of polymer electrolyte fuel cells (PEFCs) by using a dual-function micro-porous layer (MPL): Numerical simulations, International Journal of Hydrogen Energy. 38 (2013) 652-659.

[11] J. Ko, H. Ju, Effects of cathode catalyst layer design parameters on cold start behavior of polymer electrolyte fuel cells (PEFCs), International Journal of Hydrogen Energy. 38 (2013) 682-691.

[12] Y. Chang, Y. Qin, Y. Yin, J. Zhang, X. Li, Humidification strategy for polymer electrolyte membrane fuel cells - A review, Applied Energy. 230 (2018) 643-662. doi:https://doi.org/10.1016/j.apenergy.2018.08.125.

[13] J. HOU, B. YI, H. YU, L. HAO, W. SONG, Y. FU, Z. SHAO, Investigation of resided water effects on PEM fuel cell after cold start, International Journal of Hydrogen Energy. 32 (2007) 4503-4509. doi:10.1016/j.ijhydene.2007.05.004.

[14] K. Jiao, I.E. Alaefour, G. Karimi, X. Li, Cold start characteristics of proton exchange membrane fuel cells, International Journal of Hydrogen Energy. 36 (2011) 11832-11845. doi:10.1016/j.ijhydene.2011.05.101.

[15] S. Huo, K. Jiao, J.W. Park, On the water transport behavior and phase transition mechanisms in cold start operation of PEM fuel cell, Applied Energy. 233-234 (2019) 776-788. doi:https://doi.org/10.1016/j.apenergy.2018.10.068.

[16] S. Huo, N.J. Cooper, T.L. Smith, J.W. Park, K. Jiao, Experimental investigation on PEM fuel cell cold start behavior containing porous metal foam as cathode flow distributor, Applied Energy. 203 (2017) 101-114. doi:https://doi.org/10.1016/j.apenergy.2017.06.028.

[17] Z. Wan, H. Chang, S. Shu, Y. Wang, H. Tang, A Review on Cold Start of Proton Exchange Membrane Fuel Cells, Energies. 7 (2014) 3179-3203. doi:10.3390/en7053179.

[18] G. Gwak, J. Ko, H. Ju, Numerical investigation of cold-start behavior of polymer-electrolyte fuel-cells from subzero to normal operating temperatures - Effects of cell boundary and operating conditions, International Journal of Hydrogen Energy. 39 (2014) 21927-21937. doi:https://doi.org/10.1016/j.ijhydene.2014.03.143. 
[19] J. Ko, H. Ju, Comparison of numerical simulation results and experimental data during coldstart of polymer electrolyte fuel cells, Applied Energy. 94 (2012) 364-374.

doi:https://doi.org/10.1016/j.apenergy.2012.02.007.

[20] S.-Y. Lee, S.-U. Kim, H.-J. Kim, J.H. Jang, I.-H. Oh, E.A. Cho, S.-A. Hong, J. Ko, T.-W. Lim, K.-Y. Lee, T.-H. Lim, Water removal characteristics of proton exchange membrane fuel cells using a dry gas purging method, Journal of Power Sources. 180 (2008) 784-790.

doi:10.1016/j.jpowsour.2008.01.009.

[21] K. Tajiri, C.-Y. Wang, Y. Tabuchi, Water removal from a PEFC during gas purge, Electrochimica Acta. 53 (2008) 6337-6343. doi:10.1016/j.electacta.2008.04.035.

[22] P.K. Sinha, C.-Y. Wang, Gas Purge in a Polymer Electrolyte Fuel Cell, Journal of The Electrochemical Society. 154 (2007) B1158. doi:10.1149/1.2776226.

[23] S.I. Kim, N.W. Lee, Y.S. Kim, M.S. Kim, Effective purge method with addition of hydrogen on the cathode side for cold start in PEM fuel cell, International Journal of Hydrogen Energy. 38 (2013) 11357-11369. doi:https://doi.org/10.1016/j.ijhydene.2013.06.101.

[24] Y.S. Kim, S.I. Kim, N.W. Lee, M.S. Kim, Study on a purge method using pressure reduction for effective water removal in polymer electrolyte membrane fuel cells, International Journal of Hydrogen Energy. 40 (2015) 9473-9484. doi:https://doi.org/10.1016/j.ijhydene.2015.05.136.

[25] H.-Y. Tang, A.D. Santamaria, J. Bachman, J.W. Park, Vacuum-assisted drying of polymer electrolyte membrane fuel cell, Applied Energy. 107 (2013) 264-270.

[26] J. Schirmer, Brennstoffzellenvorrichtung und Verfahren zum Betrieb einer Brennstoffzellenvorrichtung, DE102015215821A1, 2015.

[27] E. Cho, J.-J. Ko, H.Y. Ha, S.-A. Hong, K.-Y. Lee, T.-W. Lim, I.-H. Oh, Effects of Water Removal on the Performance Degradation of PEMFCs Repetitively Brought to $<0^{\circ} \mathrm{C}$, J. Electrochem. Soc. 151 (2004) A661-A665.

[28] H.R. Corti, F. Nores-Pondal, M.P. Buera, Low temperature thermal properties of Nafion 117 membranes in water and methanol-water mixtures, Journal of Power Sources. 161 (2006) 799-805. doi:10.1016/j.jpowsour.2006.06.005.

[29] P. Gazdzicki, J. Mitzel, D.G. Sanchez, M. Schulze, K.A. Friedrich, Evaluation of reversible and irreversible degradation rates of polymer electrolyte membrane fuel cells tested in automotive conditions, Journal of Power Sources. 327 (2016) 86-95. doi:10.1016/j.jpowsour.2016.07.049.

[30] G. Tsotridis, A. Pilenga, G.D. Marco, T. Malkow, EU Harmonised Test Protocols for PEMFC MEA Testing in Single Cell Configuration for Automotive Applications, ISBN: 978-92-79-54132-2, 2016.

[31] K. Kinoshita, P. Stonehart, Preparation and Characterization of Highly Dispersed Electrocatalytic Materials, in: Modern Aspects of Electrochemistry, J.O. Bockris and B.E. Conway (Eds.), 1977: pp. 183-266. doi:10.1007/978-1-4615-7452-1_4. 
[32] P. Waszczuk, G.Q. Lu, A. Wieckowski, C. Lu, C. Rice, R.I. Masel, UHV and electrochemical studies of $\mathrm{CO}$ and methanol adsorbed at platinum/ruthenium surfaces, and reference to fuel cell catalysis, Electrochim. Acta. 47 (2002) 3637-3652. http://www.sciencedirect.com/science/article/pii/S0013468602003341.

[33] P. Waszczuk, A. Wieckowski, P. Zelenay, S. Gottesfeld, C. Coutanceau, J.-M. Léger, C. Lamy, Adsorption of $\mathrm{CO}$ and poison on fuel cell nanoparticle electrodes from and methanol solutions a radioactive labeling study, Journal of Electroanalytical Chemistry. 511 (2001) 55-64. doi:https://doi.org/10.1016/S0022-0728(01)00559-9.

[34] H. Kita, S. Ye, K. Sugimura, Effects of adsorbed $\mathrm{CO}$ on the electrode reactions at a platinum electrode, Journal of Electroanalytical Chemistry and Interfacial Electrochemistry. 297 (1991) 283296.

[35] T. Ruiu, A.M. Dreizler, J. Mitzel, E. Gülzow, Evaluation of a $2.5 \mathrm{kWel}$ automotive low temperature PEM fuel cell stack with extended operating temperature range up to $120^{\circ} \mathrm{C}$, J. Power Sources. 303 (2016) 257-266.

[36] J. Mitzel, P. Piela, Test Module P-10a: In-Stack Electrode Voltammetry, (2015). http://stacktest.zswbw.de/fileadmin/stacktest/docs/Information Material/Performance/TMs/TM P10a Electrochemical Method Voltammetry.pdf.

[37] P. Gazdzicki, J. Mitzel, A.M. Dreizler, M. Schulze, K. A. Friedrich, Impact of Platinum Loading on Performance and Degradation of Polymer Electrolyte Fuel Cell Electrodes Studied in a Rainbow Stack, Fuel Cells. 18 (2018) 270-278. doi:10.1002/fuce.201700099.

[38] Z. Siroma, N. Fujiwara, T. Ioroi, S. Yamazaki, K. Yasuda, Y. Miyazaki, Dissolution of Nafion ${ }^{\circledR}$ membrane and recast Nafion ${ }^{\circledR}$ film in mixtures of methanol and water, Journal of Power Sources. 126 (2004) 41-45. doi:10.1016/j.jpowsour.2003.08.024.

[39] A. Weiß, S. Schindler, S. Galbiati, M.A. Danzer, R. Zeis, Distribution of Relaxation Times Analysis of High-Temperature PEM Fuel Cell Impedance Spectra, Electrochimica Acta. 230 (2017) 391-398. doi:10.1016/j.electacta.2017.02.011.

[40] M. Pineri, G. Gebel, R.J. Davies, O. Diat, Water sorption-desorption in Nafion ${ }^{\circledR}$ membranes at low temperature, probed by micro X-ray diffraction, Journal of Power Sources. 172 (2007) 587-596. doi:10.1016/j.jpowsour.2007.05.037.

[41] S. Ge, C.-Y. Wang, Cyclic Voltammetry Study of Ice Formation in the PEFC Catalyst Layer during Cold Start, Journal of The Electrochemical Society. 154 (2007) B1399. doi:10.1149/1.2784166.

[42] S. Kim, M.M. Mench, Physical degradation of membrane electrode assemblies undergoing freeze/thaw cycling: Micro-structure effects, Journal of Power Sources. 174 (2007) 206-220. doi:10.1016/j.jpowsour.2007.08.111.

[43] Q. Yan, H. Toghiani, Y.-W. Lee, K. Liang, H. Causey, Effect of sub-freezing temperatures on a PEM fuel cell performance, startup and fuel cell components, Journal of Power Sources. 160 (2006) 1242-1250. doi:10.1016/j.jpowsour.2006.02.075. 
[44] Q. Guo, Z. Qi, Effect of freeze-thaw cycles on the properties and performance of membraneelectrode assemblies, Journal of Power Sources. 160 (2006) 1269-1274.

doi:10.1016/j.jpowsour.2006.02.093.

[45] P. Gazdzicki, P. Jakob, Methanol reactions on bimetallic Ru(0001)-based surfaces under UHV conditions., Phys. Chem. Chem. Phys. 15 (2013) 1460. doi:10.1039/c2cp42765f.

[46] FuelCellStore, http://www.fuelcellstore.com/direct-methanol-mea, http://www.fuelcellstore.com/direct-methanol-mea.

[47] C. Rabissi, P. Gazdzicki, L. Guetaz, S. Escribano, L. Grahl-Madsen, A. Baricci, A. Casalegno, A locally resolved investigation on direct methanol fuel cell uneven components fading: Steady state and degradation local analysis, Journal of Power Sources. 397 (2018) 361-373.

doi:https://doi.org/10.1016/j.jpowsour.2018.07.034.

[48] A. Heinzel, V.M. Barragán, A review of the state-of-the-art of the methanol crossover in direct methanol fuel cells, J. Power Sources. 84 (1999) 70. doi:10.1016/S0378-7753(99)00302-X.

[49] D.H. Jung, C.H. Lee, C.S. Kim, D.R. Shin, Performance of a direct methanol polymer electrolyte fuel cell, Journal of Power Sources. 71 (1998) 169-173. doi:https://doi.org/10.1016/S03787753(97)02793-6.

[50] Y. Wang, P.P. Mukherjee, J. Mishler, R. Mukundan, R.L. Borup, Cold start of polymer electrolyte fuel cells: Three-stage startup characterization, Electrochimica Acta. 55 (2010) 26362644. doi:10.1016/j.electacta.2009.12.029.

[51] DOE Technical Targets for Fuel Cell Systems and Stacks for Transportation Applications, https://www.energy.gov/eere/fuelcells/doe-technical-targets-fuel-cell-systems-and-stackstransportation-applications. 